\title{
PERSEPSI MAHASISWA TERHADAP LAYANAN NOKIA LIFE TOOL SEBAGAI INOVASI MEDIA INFORMASI PERTANIAN
}

\author{
Students Perception in Nokia Life Tool as an Information Media of Agricultural Inovation \\ Suzyant Yuanita*) dan Hadiyanto \\ Departemen Sains Komunikasi dan Pengembangan Masyarakat, Fakultas Ekologi Manusia, IPB \\ *) Email : suzyantyuanita@yahoo.co.id
}

Diterima 5 November 2010 / Disetujui 25 November 2010

\begin{abstract}
Nokia Life Tools is an innovation in agricultural sector which provide relevant information needed by farmers. One of the consequences of innovation is justification as action by the stakeholders. Agronomy and Horticultural Department students in this case are acting as one of the stackholders for the agricultural sector. The purpose of this study is to find out what the perception of students in the Agronomy and Horticultural Department class of 2006 about Nokia Life Tools watched by its characteristic as an innovation to agricultural sector. Beside that this study also have the purpose to understand the relation between internal and external factors from the Agronomy and Horticultural Department class of 2006 students with the perception about Nokia Life Tools.The result of this study shows that students in the Agronomy and Horticultural Department class of 2006 think that Nokia Life Tools giving an average advantage level, quite fit for agricultural sector, quite complicated, quite easy to be tried, and also quite easy for the result to be observed. Other result is the internal factor that related to the students in the Agronomy and Horticultural Department class of 2006 perception is the origin of the students and the students awareness level about Nokia Life Tools., and the external factor is the students exposure level of the Nokia Life Tools advertisement.
\end{abstract}

Keywords: nokia life tools, internal factor, external factor, perception

\section{PENDAHULUAN}

\section{Latar Belakang}

Pertanian merupakan sektor penting bagi sejumlah penduduk Indonesia. Menurut catatan Departemen Pertanian tahun 2007 jumlah petani di Indonesia sekitar 50 persen dari jumlah penduduk Indonesia atau sekitar 110 juta. ${ }^{1}$ Data tersebut mengindikasikan bahwa sebagian besar penduduk Indonesia berprofesi sebagai petani. Salah satu yang menjadi kebutuhan petani saat ini adalah informasi untuk sektor pertanian. Informasi pertanian menjadi penting karena merupakan salah satu upaya untuk memberdayakan masyarakat petani serta meningkatkan taraf hidup dan kesejahteraan petani. Seperti dinyatakan oleh Mulyandari dan Eko (2005) bahwa beberapa hasil penelitian bidang pertanian berupa informasi baik dalam hal teknik produksi maupun pemasaran pada dasarnya adalah upaya untuk memperbaiki atau memecahkan masalah yang ada dalam bidang pertanian itu sendiri.

Nokia Life Tools merupakan layanan berbasis SMS mengenai agrikultur (pertanian), edukasi (pendidikan), dan hiburan. Fungsi utama Nokia Life Tools adalah memberikan informasi yang relevan bagi petani untuk meningkatkan kesejahteraan petani tersebut, diantaranya harga jual hasil panen, ramalan cuaca, serta tips bercocok tanam. Nokia Life Tools sebagai inovasi layanan informasi pertanian yang masih baru tentunya memiliki suatu konsekuensi. Konsekuensi yang berlaku untuk suatu inovasi adalah kemungkinan-kemungkinan tanggapan atau penilaian dari stakeholder yang berperan dalam bidang pertanian.

Mahasiswa yang fokus studinya di bidang pertanian merupakan salah satu stakeholder dalam bidang pertanian. Dimana dalam hal ini mahasiswa Departemen Agronomi dan Hortikultura sebagai mahasiswa pertanian dianggap cukup memiliki peran dalam mempengaruhi masyarakat petani. Oleh karena itu dalam penelitian ini, dimana Nokia Life Tools yang diposisikan sebagai inovasi untuk sektor pertanian perlu untuk dipersepsikan oleh mahasiwa Departemen Agronomi dan Hortikultura. Persepsi tersebut diperlukan untuk menilai baik atau tidaknya layanan Nokia Life Tools sebagai suatu inovasi media informasi pertanian. Dengan demikian perlu dilakukan penelitian untuk mengetahui persepsi mahasiswa dalam menilai Nokia Life Tools sebagai inovasi layanan yang menyediakan berbagai informasi seputar bidang pertanian.

\footnotetext{
1 Anonim. 2009. Revolusi Hijau, Menjerat Petani dengan Racun. http://www.rumahtulisan.com/25/05/2009/kliping/revolusi-hijaumenjerat-petani-denganracun. html diakses tanggal 25 Mei 2010
} 


\section{Perumusan Masalah}

1. Bagaimana karakteristik personal dan tingkat keterdedahan terhadap informasi mahasiswa Departemen Agronomi dan Hortikultura tahun masuk 2006 ?

2. Bagaimana persepsi mahasiswa Departemen Agronomi dan Hortikultura tahun masuk 2006 mengenai layanan Nokia Life Tools?

3. Bagaimana hubungan karakteristik personal dan tingkat keterdedahan terhadap informasi dengan persepsi mahasiswa Departemen Agronomi dan Hortikultura tahun masuk 2006 mengenai layanan Nokia Life Tools sebagai inovasi media informasi pertanian?

\section{Tujuan Penelitian}

1. Mendeskripsikan karakteristik personal dan tingkat keterdedahan terhadap informasi mahasiswa Departemen Agronomi dan Hortikultura tahun masuk 2006.

2. Mendeskripsikan persepsi mahasiswa Departemen Agronomi dan Hortikultura tahun 2006 mengenai layanan Nokia Life Tools sebagai inovasi media informasi pertanian.

3. Menganalisis hubungan karakteristik personal dan tingkat keterdedahan terhadap informasi dengan persepsi mahasiswa Departemen Agronomi dan Hortikultura tahun masuk 2006 mengenai layanan Nokia Life Tools sebagai inovasi media informasi pertanian.

\section{PENDEKATAN TEORITIS}

\section{Tinjauan Pustaka}

\section{Pengertian Persepsi}

Persepsi dalam pengertian psikologi adalah proses pencarian informasi untuk dipahami melalui alat penginderaan dengan kesadaran atau kognisi. Alat untuk memperoleh informasi tersebut adalah penginderaan (penglihatan, pendengaran, peraba, dan sebagainya). Sebaliknya alat untuk memahaminya adalah kesadaran atau kognisi (Sarwono, 2002). Selanjutnya menurut Rakhmat (2001), persepsi adalah pengalaman mengenai objek, peristiwa, atau hubungan yang diperoleh dengan menyimpulkan informasi dan menafsirkan objek yang melibatkan sensasi, atensi, ekspektasi, motivasi, dan memori.

Menurut Mulyana (2001), persepsi adalah proses internal yang memungkinkan kita memilih, mengorganisasikan, dan menafsirkan rangsangan dari lingkungan, dan proses tersebut mempengaruhi perilaku kita. Persepsi disebut sebagai inti komunikasi karena jika persepsi kita tidak akurat, tidak mungkin kita berkomunikasi dengan efektif. Persepsi yang menentukan kita memilih suatu pesan dan mengabaikan pesan yang lain. Semakin tinggi derajat kesamaan persepsi antar individu, semakin mudah, dan semakin sering mereka berkomunikasi, dan sebagai konsekuensinya semakin cenderung membentuk kelompok budaya atau kelompok identitas.

\section{Proses Persepsi}

Menurut Krech dan Crutchfield (1977) dalam Rakhmat (2001), terdapat empat prinsip dasar dalam proses pembentukkan persepsi, yaitu:

1. Persepsi dipengaruhi oleh karakteristik orang yang memberikan respon pada stimulus yang diterima. Artinya seseorang akan memberikan suatu arti tertentu terhadap stimulus yang dihadapinya, walaupun arti dan maksud stimulus tidak sesuai dengan arti persepsi orang tersebut.

2. Persepsi yang bersifat selektif secara fungsional dimana seseorang dalam mempersepsikan suatu stimulus melalui proses pemilihan.

3. Persepsi yang selalu diorganisasikan dan diberi arti memiliki suatu medan kesadaran yang memberi struktur terhadap gambaran yang muncul kemudian. Disamping itu keadaan lingkungan sosial seseorang akan mempengaruhi proses pembentukan persepsi.

4. Persepsi yang ditentukan oleh sifat-sifat struktur secara keseluruhan. Jika dianggap sebagai anggota kelompok, semua sifat individu yang berkaitan dengan sifat kelompok akan dipengaruhi oleh keanggotaan kelompoknya melalui efek pembauran.

Menurut Setiadi (2003), persepsi merupakan proses yang terdiri dari seleksi, organisasi, dan interpretasi terhadap stimulus. Penjelasan masing-masing proses pembentukan persepsi adalah sebagai berikut:

\section{Seleksi Perseptual}

Seleksi perseptual terjadi ketika seseorang menangkap dan memilih stimulus berdasarkan pada psychology set yang dimiliki yaitu berbagai informasi yang ada dalam memori orang tersebut. Sebelum seleksi persepsi terjadi, terlebih dahulu stimulus harus mendapat perhatian dari seseorang.

2. Organisasi Persepsi

Organisasi persepsi berarti bahwa seseorang mengelompokkan informasi dari berbagai sumber ke dalam pengertian yang menyeluruh untuk memahami lebih baik dan bertindak atas pemahaman. Prinsip dasar dari organisasi persepsi adalah penyatuan dari berbagai stimulus akan dirasakan sebagai suatu yang dikelompokkan secara menyeluruh. Pengorganisasian seperti ini memudahkan untuk memproses informasi dan memberikan pengertian yang terintegrasi terhadap stimulus.

3. Interpretasi Perseptual

Proses terakhir dari persepsi adalah memberikan interpretasi atas stimulus yang diterima seseorang. Setiap stimulus yang menarik perhatian baik yang disadari maupun tidak, akan diinterpretasikan. Seseorang akan membuka kembali berbagai informasi yang telah tersimpan dalam memorinya di dalam proses ini.

\section{Faktor-faktor Persepsi}

Persepsi individu terhadap sesuatu tidak semata-mata terbentuk begitu saja, melainkan ada beberapa faktor yang 
mempengaruhi interpretasinya terhadap suatu objek. Menurut Krech dan Crutchfield (1977) dalam Rakhmat (2001) ada dua faktor yang mempengaruhi persepsi, yaitu:

1. Faktor fungsional berasal dari kebutuhan, pengalaman masa lalu, dan hal-hal lain yang kita sebut sebagai faktor personal. Dalam hal ini yang membentuk persepsi bukan jenis atau bentuk stimulus tersebut. Faktor fungsional yang membentuk persepsi biasanya disebut sebagai kerangka rujukan (frame of reference). Dalam kegiatan komunikasi, kerangka rujukan mempengaruhi bagaimana orang memberi makna pada pesan yang diterimanya.

2. Faktor struktural berasal dari semata-mata sifat stimulus fisik dan efek saraf individu.

Merujuk pada teori tersebut dapat diketahui bahwa faktor fungsional berupa faktor internal yang terdapat dalam diri individu, sedangkan faktor struktural berupa faktor eksternal yang berasal dari stimulus secara fisik dan efek saraf individu dalam menerima stimulus.

\section{Pengertian Inovasi}

Pengertian inovasi menurut Rogers (2003) merupakan segala sesuatu menyangkut ide, cara-cara, ataupun objek yang dianggap baru oleh seseorang (individu). Sementara itu Mardikanto (1998) menjelaskan bahwa pengertian inovasi dapat diperluas menjadi sesuatu ide, perilaku, produk, informasi, dan praktek-praktek baru yang belum banyak diketahui, diterima, dan digunakan atau dilaksanakan oleh sekelompok orang dalam suatu lokalitas tertentu untuk melakukan perubahan tertentu di bidang ekonomi, politik, dan sosial budaya demi tercapainya perbaikan mutu hidup masyarakat yang bersangkutan.

Menurut Ibrahim (2003), inovasi dapat berupa barang (fisik) dan bukan barang (nonfisik). Inovasi yang bersifat fisik dapat menimbulkan konsekuensi tindakan-tindakan konkret yang mudah dalam menilai keberhasilannya, seperti terasering, reboisasi, dan pola tanam. Di sisi lain inovasi yang bersifat non-fisik dapat menimbulkan tindakantindakan yang sulit untuk menilai keberhasilannya, seperti kesadaran hukum dan kesadaran menjadi anggota koperasi.

\section{Karakteristik Inovasi}

Interpretasi terhadap suatu inovasi dapat dilakukan dengan menilai atribut atau karakteristik yang ada pada inovasi tersebut. Menurut Rogers (2003) karakteristik inovasi yang dapat dirasakan oleh individu adalah sebagai berikut:

\section{Keuntungan Relatif}

Keuntungan relatif adalah derajat/tingkat bagi suatu inovasi yang dirasa lebih baik daripada gagasan lain. Derajat tingkat dari keuntungan yang relatif mungkin terukur dalam terminologi ekonomi, tetapi faktor gengsi sosial, kenyamanan, dan kepuasan juga merupakan faktor yang penting. Semakin besar keuntungan untuk adopter yang dirasakan dari suatu inovasi, akan semakin cepat tingkat adopsinya.

2. Kesesuaian
Kesesuaian merupakan derajat/tingkat kekonsistenan suatu inovasi dengan nilai-nilai yang ada, pengalaman masa lalu, dan kebutuhan orang yang potensial. Suatu gagasan yang tidak cocok atau bertentangan dengan norma dan nilai suatu sistem sosial tidak akan diadopsi dengan cepat sebagai suatu inovasi.

\section{Kerumitan}

Kerumitan merupakan derajat/tingkat kesulitan untuk dipahami dan digunakan bagi suatu inovasi. Ada beberapa inovasi yang siap dipahami oleh kebanyakan anggota dari suatu sistem sosial, sedangkan beberapa lainnya lebih rumit untuk dipahami.

4. Kemudahan dicoba

Kemudahan dicoba merupakan derajat/tingkat kemudahan suatu inovasi untuk dicoba dalam skala kecil.

\section{Kemudahan diamati}

Kemudahan diamati merupakan derajat/tingkat hasil inovasi tersebut terlihat oleh orang lain. Semakin mudah untuk individu melihat hasil dari suatu inovasi, maka semakin mungkin bagi mereka untuk mengadopsi.

\section{Tahapan Keputusan Inovasi}

Keputusan inovasi terdiri dari lima tahap, yaitu 1) tahap pengetahuan, 2) tahap persuasi, 3) tahap keputusan, 4) tahap implementasi, 5) tahap konfirmasi (Rogers, 2003). Berikut merupakan penjelasan masing-masing tahap pengambilan keputusan terhadap suatu inovasi:

1. Tahap pengenalan (pengetahuan)

Tahap pengenalan terjadi ketika individu membuka diri terhadap keberadaan inovasi dan memperoleh beberapa pengertian mengenai bagaimana inovasi tersebut berfungsi. Informasi yang diterima oleh individu atau unit pembuat keputusan ini masih bersifat umum.

\section{Tahap persuasi}

Tahap ini terjadi ketika individu atau unit pembuat keputusan yang lain membentuk sikap senang atau tidak senang terhadap inovasi. Pada tahap ini seseorang terlibat secara psikologis dengan inovasi dan giat mencari keterangan atau informasi mengenai informasi.

\section{Tahap keputusan}

Tahap ini terjadi bila individu atau unit pembuat keputusan yang lain dihadapkan pada situasi untuk menentukan pilihan apakah akan menerima atau menolak inovasi.

\section{Tahap implementasi}

Tahap ini terjadi ketia individu atau unit pembuat keputusan yang lain mulai menjalankan atau melaksanakan apa yang telah diputuskannya pada tahap keputusan.

\section{Tahap konfirmasi}


Tahap ini terjadi ketika individu atau unit pembuat keputusan yang lain mencoba memperkuat keputusan inovasi atau sebaliknya menarik keputusan inovasi. Seseorang dapat berubah pikiran dari yang sudah menerima keputusan inovasi menjadi menolak inovasi dan sebaliknya.

\section{Ponsel sebagai Media Komunikasi}

Media merupakan salah satu unsur dalam proses komunikasi. Menurut Cangara (2006), media komunikasi adalah alat atau sarana yang digunakan untuk meyampaikan pesan dari komunikator kepada khalayak. Menurut Darwin dalam Rahardjo (2002), ponsel merupakan alat komunikasi yang dapat mengirimkan dan menerima pesan. Ponsel sebagai peralatan yang praktis untuk melakukan komunikasi dimanapun berada tanpa dibatasi oleh ruang dan rentang panjang kabel (Mulyanta, 2003). Dengan demikian dapat dikatakan bahwa ponsel merupakan alat atau media yang dapat meneruskan pesan komunikasi dengan bahasa.

Telepon seluler memiliki kelebihan dibandingkan dengan media komunikasi lainnya, yaitu dalam hal pengiriman dan penerimaan pesan. Karakteristik telepon seluler yang menjadi kelebihan alat tersebut sebagai media komunikasi adalah memungkinkan terjadinya komunikasi dua arah secara penuh tanpa perlu bergantian (interaktif), sehingga ponsel disebut sebagai sistem telepon nirkabel (Sunomo, 2003).

Menurut Suhendar (2003), ponsel pada umumnya dipakai oleh banyak orang karena dilengkapi dengan aplikasi untuk pengiriman pesan. Aplikasi tersebut berkembang secara pesat dalam beberapa tahun terakhir, mulai dari Short Messaging Service (SMS), Enhanched Message Service (EMS), dan Multimedia Message Service (MMS). Penggunaan ponsel paling tinggi adalah aplikasi SMS, karena aplikasi tersebut merupakan cara berkomunikasi yang paling murah untuk mengirim pesan.

Berdasarkan karakteristik media komunikasi menurut Ruben (1992) dalam Mugniesyah (2010), telepon seluler memiliki karakteristik sebagai media komunikasi sebagai berikut: 1) sinkron, karena ponsel memungkinkan proses komunikasi dimanapun berada tanpa dibatasi ruang dan waktu; 2) interaktivitas tinggi, karena kontrol isi pesan, waktu, dan tempat terjadinya komunikasi sepenuhnya ada di pengguna ponsel; 3) presensi tinggi, karena komunikasi dengan menggunakan media ponsel memungkinkan terjadinya komunikasi yang personal (pribadi); 4) bersifat pribadi, karena ponsel merupakan alat komunikasi interpersonal yang hanya melibatkan individu dalam proses komunikasi.

\section{Kerangka Pemikiran}

Nokia Life Tools merupakan suatu inovasi media informasi untuk sektor pertanian.Sebagai suatu inovasi, tentunya Nokia Life Tools menimbulkan konsekuensi dari pihak terkait (stakeholder) untuk menilai inovasi sebelum mengambil keputusan atas inovasi tersebut. Persepsi merupakan salah satu cara untuk menilai baik atau tidaknya inovasi tersebut. Melalui proses persepsi dari pihak-pihak terkait, kita dapat mengetahui kemampuan yang dimiliki inovasi dilihat dari karakteristik atau atribut yang melekat pada inovasi tersebut.

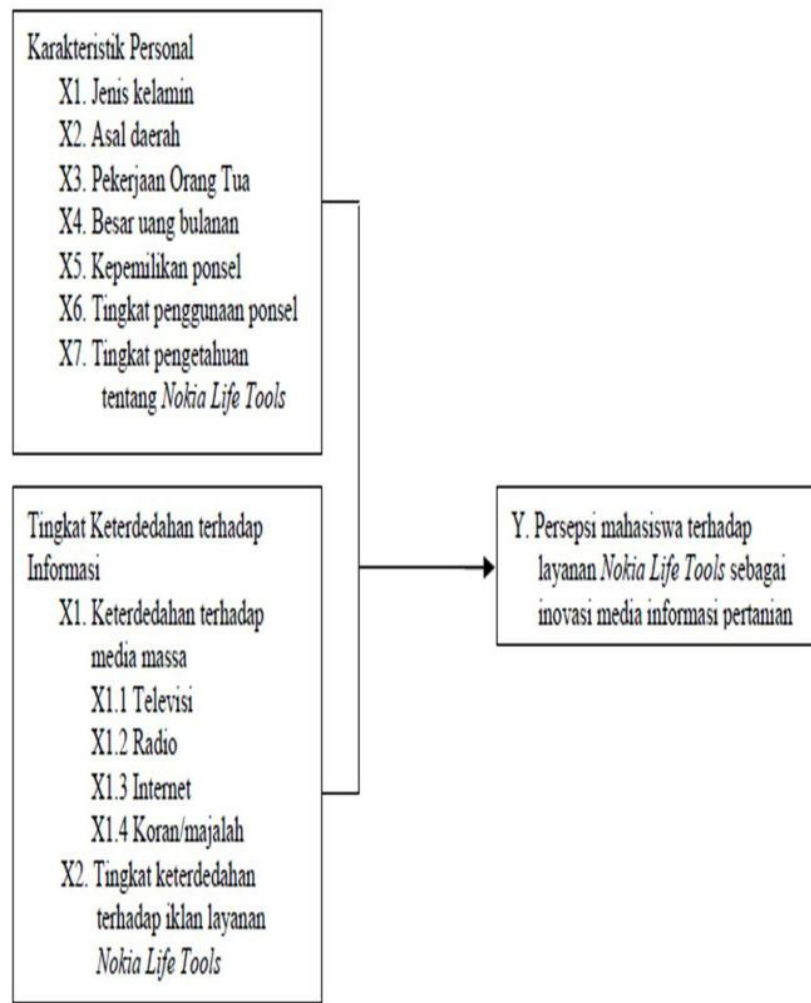

Gambar 3. Kerangka Pemikiriall

Salah satu pihak yang terkait dalam bidang pertanian adalah mahasiswa yang memiliki fokus studi pada bidang pertanian. Mahasiswa dianggap memiliki posisi strategis dalam mempengaruhi masyarakat. Oleh karena itulah persepsi dari mahasiswa pertanian diperlukan untuk menilai baik atau tidaknya Nokia Life Tools, sebagai suatu inovasi yang digunakan oleh petani dalam mengembangkan usaha pertaniannya.

Penelitian ini bertujuan untuk mengetahui persepsi mahasiswa Departemen Agronomi dan Hortikultura terhadap Nokia Life Tools sebagai suatu inovasi media informasi pertanian. Persepsi individu dipengaruhi oleh beberapa faktor, diantaranya adalah faktor internal dan faktor eksternal. Faktor internal berasal dari karakteristik yang melekat pada individu. Faktor eksternal berasal dari sifat stimulus yang dapat mempengaruhi persepsi seseorang terhadap objek. Pada penelitian ini untuk mengetahui persepsi mahasiswa dilihat berdasarkan kedua faktor tersebut.

\section{Hipotesis Penelitian}

Hipotesis yang diajukan dalam penelitian ini adalah:

1. Diduga ada hubungan antara karakteristik personal dengan persepsi mahasiwa terhadap layanan Nokia Life Tools sebagai inovasi media informasi pertanian.

2. Diduga ada hubungan antara tingkat keterdedahan terhadap informasi dengan persepsi terhadap layanan Nokia Life Tools sebagai inovasi media informasi pertanian. 


\section{PENDEKATAN LAPANG}

\section{Metode Penelitian}

Metode penelitian yang digunakan dalam penelitian ini adalah pendekatan kuantitatif. Tipe penelitian ini adalah deskriptif, dimana di dalamnya terdapat upaya mendeskripsikan, mencatat, analisis, dan menginterpretasikan kondisi-kondisi yang sedang terjadi dengan melihat kaitan antara variabel-variabel yang ada (Mardalis, 2004).

Pendekatan kuantitatif dilakukan dengan menggunakan metode survey, yaitu penelitian yang mengambil sampel dari populasi dan menggunakan kuesioner sebagai alat pengumpul data primer, dan individu sebagai unit analisa (Singarimbun dan Effendi, 1995).

\section{Jenis Data dan Teknik Pengumpulan Data}

Jenis data yang digunakan dalam penelitian ini adalah data primer dan data sekunder. Data primer diperoleh dari penelitian langsung di lapangan dengan mengunakan kuesioner dan wawancara mendalam. Data sekunder diperoleh dari website vendor Nokia mengenai profil layanan Nokia Life Tools. Selain itu juga dilakukan studi literatur yang berkaitan dengan tujuan penelitian seperti buku, artikel, skripsi, tesis, dan karya ilmiah lainya.

Uji validitas dan realibilitas dilakukan sebelum pengumpulan data pada responden sasaran. Uji validitas menunjukkan sejauh mana data yang ditampung pada kuesioner dapat mengukur apa yang ingin diukur (Umar, 2003). Teknik analisis untuk menguji validitas dari instrumen pengumpulan data menggunakan teknik korelasi Product Moment (Pearson). Menurut hasil korelasi pearson, bila nilai $\mathrm{r}>$ rtabel maka pernyataan tersebut valid. Uji realibilitas bertujuan mengetahui kekonsistenan, keterandalan, dan kestabilan alat ukur didalam mengukur gejala yang sama (Umar, 2003). Pengukuran uji realibilitas dilakukan dengan teknik Alpha Cronbach. Hasil pengukuran didapatkan koefisien realibilitas sebesar 0,781 sehingga kuesioner dapat diandalkan untuk dijadikan alat ukur pada penelitian ini.

\section{Waktu dan Tempat Penelitian}

Penelitian ini dilakukan di kampus Institut Pertanian Bogor. Tempat penelitian ini dipilih secara purposive (sengaja) dengan pertimbangan bahwa responden yang dipilih pada penelitian ini adalah Mahasiswa Institut Pertanian Bogor. Sebagian besar waktu mahasiswa dihabiskan di kampus. Dengan demikian kampus Institut Pertanian Bogor cocok sebagai tempat penyebaran kuesioner dan melakukan penelitian. Penelitian ini berlangsung selama satu bulan yakni pada bulan Juni-Juli 2010 .

\section{Metode Pengambilan Sampel}

Populasi dalam penelitian ini adalah mahasiswa Institut Pertanian Bogor, Departemen Agronomi dan Hortikultura tahun masuk 2006. Pemilihan populasi dilakukan secara purposive (sengaja) dengan mempertimbangkan kesesuaian topik penelitian dengan kebutuhan responden. Responden dipilih dengan metode pengambilan sampel incidental sampling dengan sebelumnya telah dipilih mahasiswa Departemen Agronomi dan Hortikultura tahun masuk 2006 sebagai populasi. Pemilihan populasi tersebut dengan pertimbangan karakteristik responden yang disesuaikan dengan penelitian ini, yaitu mahasiswa yang fokus studinya dalam bidang pertanian dan sudah cukup pengalaman dan pengetahuannya mengenai bidang pertanian di lapang. Beberapa peneliti menyatakan bahwa besarnya sampel tidak boleh kurang dari 10 persen dari populasi. Populasi dalam penelitian ini tergolong dalam skala kecil, dimana populasi mahasiswa Departemen Agronomi dan Hortikultura tahun masuk 2006 sebesar 151 orang.

Jumlah sampel untuk populasi skala kecil dapat diambil minimal untuk data sebaran normal yaitu 30 kasus (Singarimbun dan Effendi, 1989). Berdasarkan penjelasan tersebut, maka jumlah sampel yang akan diambil dalam penelitian ini adalah sebanyak 40 responden agar hasil penelitian dapat lebih representatif.

\section{Pengolahan dan Analisis Data}

Data yang diperoleh dianalisis secara kuantitatif. Pengolahan data dilakukan dengan terlebih dahulu melakukan pengkodean. Kegiatan ini bertujuan untuk menyeragamkan data. Selanjutnya melakukan penghitungan skor akhir. Masing-masing skor akhir pada tiap variabel dibagi sesuai dengan kategori yang telah ditentukan dengan rumus sebagai berikut:

\section{Rentang kelas $=\frac{\text { skor maksimum-skor minimum }}{\text { Jumlah kategori }}$}

Data yang dikumpulkan selanjutnya diolah secara statistik deskriptif dengan mengunakan software SPSS for Windows versi 11.5 dan Microsoft Excel 2007. Statistik deskriptif diolah menggunakan tabel frekuensi dan tabulasi silang (crosstab), untuk mengetahui karakteristik mahasiswa, tingkat keterdedahan mahasiswa terhadap iklan layanan Nokia Life Tools, tingkat pengetahuan mahasiswa mengenai Nokia Life Tools, dan persepsi mahasiswa terhadap layanan Nokia Life Tools. Uji korelasi chi-square, untuk melihat hubungan antar variabel data nominal. Rank Spearman digunakan untuk mengetahui hubungan antar dua variabel yang berskala ordinal dan tidak menemukan prasyarat data terdistribusi normal.

\section{HASIL DAN PEMBAHASAN}

\section{Persepsi Responden Mengenai Nokia Life Tools}

Persepsi mahasiswa mengenai layanan Nokia Life Tools merupakan interpretasi atau penilaian mahasiswa Departemen Agronomi dan Hortikultura tahun masuk 2006 yang menjadi responden mengenai layanan Nokia Life Tools sebagai suatu inovasi yang menyediakan berbagai informasi untuk pertanian. Interpretasi tersebut dilihat berdasarkan lima karakteristik inovasi yang ada pada layanan Nokia Life Tools, yaitu tingkat keuntungan relatif inovasi, tingkat kesesuaian inovasi, tingkat kerumitan inovasi, tingkat kemudahan inovasi untuk dicoba, dan tingkat kemudahan inovasi untuk dilihat hasilnya.

Pada penelitian ini persepsi responden mengenai Nokia Life Tools dinilai dari lima indikator karakteristik inovasi, dimana pada masing-masing karakteristik tersebut diberi 
skor dan dibagi ke dalam masing-masing kategori. Data mengenai persepsi responden mengenai kelima karakteritik inovasi disajikan pada Tabel 1.

Data pada Tabel 1 menunjukkan persepsi mahasiswa Departemen Agronomi dan Hortikultura tahun masuk 2006 yang menjadi responden pada penelitian ini mengenai masing-masing karakteristik inovasi yang dimiliki layanan Nokia Life Tools. Karakteristik yang pertama yaitu keuntungan relatif, dari 40 responden, sebanyak 87,5 persen menyatakan Nokia Life Tools memiliki tingkat keuntungan relatif yang sedang, lima persen menyatakan rendah, dan 7,5 persen menyatakan tinggi.

Nokia Life Tools merupakan layanan yang dapat menyediakan informasi seputar pertanian, seperti harga pasar untuk komoditas pertanian, tips bercocok tanam, dan info cuaca. Informasi tersebut dapat dengan mudah diperoleh oleh petani dengan mengirim SMS berlangganan dengan tarif Rp. 1000,00 per harinya atau Rp. 30.000,00 per bulan, kemudian pengguna dapat memilih layanan informasi apa saja yang dibutuhkan. Dalam satu hari berapa pun jumlah SMS yang diterima, biaya yang dikenakan tetap sama. Informasi komoditas yang ditawarkan mulai dari bibit, ternak, hortikultura, dan perikanan.

Berbagai jenis informasi seputar pertanian yang ditawarkan oleh layanan Nokia Life Tools, tentunya Nokia Life Tools dapat memberikan keuntungan tersendiri bagi pengguna dibandingkan dengan media informasinya lainnya, seperti televisi, radio, internet, koran/majalah. Apalagi dengan tarif yang ditawarkan cukup murah yaitu hanya Rp. 1000,00 per hari. Berbagai kelebihan yang ditawarkan layanan tersebut menjadi alasan responden dalam penelitian ini menyatakan bahwa layanan tersebut cukup dapat memberikan keuntungan bagi penggunanya, walaupun tingkat keuntungan yang diberikan tidak terlalu tinggi.

\section{Iabel 1. Persepsi Responden terhadap Karakteristik Inovasi. Nokia Life Tools}

\begin{tabular}{|c|c|c|}
\hline Persepsi Mahasiswa (skor) & Jumlah (orang) & Persentase $(\%)$ \\
\hline Tingkat Keuntungan Relatif & & \\
\hline Rendah $(4-8)$ & 2 & 5,0 \\
\hline Sedang (9-12) & 35 & 87,5 \\
\hline Tinggi (13-16) & 3 & 7,5 \\
\hline Tingkat Kesesuaian & & \\
\hline Tidak sesuai $(4-8)$ & 3 & 7,5 \\
\hline Cukup sestuai (9-12) & 35 & 87,5 \\
\hline Sangat sesuai (13-16) & 2 & 5,0 \\
\hline Tingkat Kerumitan & & \\
\hline Cukup rumit (9-12) & 26 & 65,0 \\
\hline Sangat rumit (4.8) & 14 & 35,0 \\
\hline Tingkat Kemudahan dicoba & & \\
\hline Tidak mudah (4-8) & 11 & 27,5 \\
\hline Cukup mudah $(9-12)$ & 27 & 67,5 \\
\hline Sangat mudah (13-16) & 2 & 5,0 \\
\hline Tingkat Kemudahan dilihat Hasilnya & & \\
\hline Tidak mudah $(4-8)$ & 5 & 12,5 \\
\hline Cukup mudah (9-12) & 35 & 87,5 \\
\hline
\end{tabular}

Persepsi responden mengenai tingkat kesesuaian layanan Nokia Life Tools dikategorikan menjadi tiga, yaitu tidak sesuai, cukup sesuai, dan sangat sesuai. Pada Tabel 1 terlihat bahwa sebanyak 87,5 persen menyatakan Nokia Life Tools cukup sesuai, 7,5 persen memilih tidak sesuai, dan lima persen lainnya memilih sangat sesuai. Dari hasil tersebut dapat diketahui bahwa sebagian besar mahasiswa Departemen Agronomi dan Hortikultura tahun masuk 2006 yang menjadi responden menyatakan bahwa Nokia Life Tools cukup sesuai sebagai inovasi untuk kebutuhan informasi mengenai bidang pertanian saat ini.

Nokia Life Tools menyediakan informasi yang relevan seputar pertanian bagi masyarakat pedesaan terutama petani, seperti harga jual hasil panen, tips bercocok tanam, dan informasi prakiraan cuaca. Semua informasi tersebut sangat spesifik tergantung lokasi dan hasil panen yang telah dipilih. Lokasi disesuaikan dengan kode pos yang dikirimkan pengguna pada saat mendaftar SMS berlangganan layanan ini. Selain agrikultur, Nokia Life Tools menyediakan layanan lainnya seperti edukasi dan hiburan.

Berbagai layanan yang ditawarkan Nokia Life Tools disesuaikan dengan kebutuhan masyarakat di daerah pedesaan, terutama para petani. Mengingat yang menjadi sasaran utama layanan ini adalah petani. Hal ini dapat dilihat dari pernyataan pihak Nokia bahwa keputusannya dalam menyediakan ketiga jenis layanan berupa agrikultur, edukasi, dan hiburan merupakan hasil riset para ahli antropologi yang mengamati perilaku dan mendengarkan masukan dari berbagai kalangan di daerah pedesaan.

Berbagai usaha telah dilakukan pihak Nokia untuk dapat menyediakan layanan yang sesuai dengan kebutuhan masyarakat yang menjadi sasaran utama layanan ini. Oleh karena itulah pantas apabila layanan ini dinilai memiliki tingkat kesesuaian yang sedang atau dianggap cukup sesuai dengan kebutuhan informasi pertanian saat ini, terutama para petani sebagai sasaran utama dari layanan ini.

Persepsi responden mengenai tingkat kerumitan Nokia Life Tools berdasarkan Tabel 10 menunjukkan hasil bahwa sebanyak 65 persen responden mempersepsikan Nokia Life Tools cukup rumit, sisanya 35 persen mempersepsikan sangat rumit, dan tidak ada mahasiswa yang mempersepsikan tidak rumit. Berdasarkan hasil tersebut dapat diketahui bahwa sebagian besar mahasiswa Departemen Agronomi dan Hortikultura tahun masuk 2006 yang menjadi responden menilai bahwa Nokia Life Tools cukup rumit, namun tidak sedikit juga yang mempersepsikan Nokia Life Tools sangat rumit.

Nokia Life Tools yang berbasiskan sistem SMS tentu akan mempermudah bagi pengguna untuk mengakses layanan ini. Dengan basis SMS, pengguna hanya perlu mendaftar SMS berlangganan yang dikenakan tarif Rp. 1000,00 per hari. Basis SMS tentu akan dirasakan dirasakan lebih mudah dibandingkan dengan internet, karena SMS dapat digunakan kapanpun dan dimanapun tanpa perlu mengatur setting dan perlunya jangkauan GPRS. Pihak Nokia telah mempertimbangkan hal ini sebelumnya dengan alasan sasaran layanan ini masyarakat di pedesaan atau daerah terpencil, dimana belum seluruh daerah di Indonesia terutama di daerah pedesaan dapat mengakses internet. 
Persepsi responden mengenai tingkat kemudahan Nokia Life Tools untuk dicoba berdasarkan Tabel 10 menunjukkan bahwa sebanyak 67,5 persen menyatakan bahwa Nokia Life Tools cukup mudah untuk dicoba, 27,5 persen menyatakan tidak mudah, dan lima persen sisanya menyatakan Nokia Life Tools sangat mudah untuk dicoba. Berdasarkan hasil tersebut dapat diketahui bahwa lebih dari setengah mahasiswa Departemen Agronomi dan Hortikultura tahun masuk 2006 yang menjadi responden mempersepsikan Nokia Life Tools tergolong cukup mudah untuk dicoba sebagai inovasi untuk pertanian.

Nokia Life Tools dinilai cukup rumit dan cukup mudah pula untuk dicoba oleh sebagian besar responden dalam penelitian ini. Hal tersebut dikarenakan berbagai kemudahan yang dibuat pihak Nokia dalam hal penggunaan layanan Nokia Life Tools. Kemudahan yang diberikan sengaja ditujukan bagi sasaran utama layanan ini, yaitu masyarakat petani. Hal tersebut dapat menjadi alasan responden menilai bahwa layanan Nokia Life Tools masih cukup mudah untuk dicoba oleh siapa saja, kapan saja, dan dimana saja, tidak terkecuali oleh masyarakat petani sebagai sasaran utama layanan ini.

Persepsi responden mengenai kemudahan Nokia Life Tools untuk dilihat hasilnya pada Tabel 10 dapat diketahui bahwa sebanyak 87,5 persen menyatakan Nokia Life Tools cukup mudah untuk dilihat hasilnya, 12,5 persen menyatakan tidak mudah, dan tidak ada yang menyatakan Nokia Life Tools sangat mudah untuk dilihat hasilnya. Berbagai manfaat yang ditawarkan pihak Nokia tidak sesuai dengan apa yang dipersepsikan responden. Pada penelitian ini responden menilai bahwa Nokia Life Tools tidak dapat dengan mudah memberi manfaat atau hasil bagi sektor pertanian saat ini, karena berdasarkan pengalamannya selama di lapang, mahasiswa Departemen Agronomi dan Hortikultura yang menjadi responden sudah memahami bahwa petani selama ini, terutama petani kecil sudah sangat tergantung dengan para tengkulak. Selama ini petani hanya dapat menjual hasil panennya kepada para tengkulak, sehingga cenderung pasrah dengan harga yang ditetapkan tengkulak atas hasil panen mereka. Oleh karena itulah informasi mengenai harga jual hasil panen dalam Nokia Life Tools dianggap tidak terlalu mudah untuk memberikan manfaat secara langsung bagi sektor pertanian saat ini ditinjau dari sasaran utama layanan ini yaitu para petani, terutama petani kecil.

Keseluruhan persepsi mengenai layanan Nokia Life Tools merupakan akumulasi skor dari persepsi dari masingmasing karakteristik yang dimiliki Nokia Life Tools sebagai suatu inovasi, yaitu keuntungan relatif, kesesuaian, kerumitan, kemudahan untuk dicoba, dan kemudahan untuk dilihat hasilnya. Persepsi responden mengenai Nokia Life Tools sebagai suatu inovasi media informasi pertanian dikategorikan menjadi dua, yaitu baik dan buruk. Persepsi ini untuk melihat penilaian baik buruknya layanan Nokia Life Tools sebagai suatu inovasi dalam menyediakan informasi pertanian. Persepsi responden mengenai Nokia Life Tools disajikan pada Tabel 2.

Merujuk data Tabel 2 dapat diketahui persepsi responden mengenai Nokia Life Tools yaitu, sebanyak 27,5 persen mempersepsikan Nokia Life Tools tidak baik, sedangkan 72,5 persen mempersepsikan baik. Berdasarkan hasil tersebut dapat diketahui bahwa sebagian besar mahasiswa Departemen Agronomi dan Hortikultura tahun masuk 2006 yang menjadi responden pada penelitian ini menilai bahwa layanan Nokia Life Tools sebagai suatu inovasi yang baik dalam menyediakan informasi pertanian, sehingga cocok untuk dimanfaatkan sebagai suatu media informasi pertanian. Hasil berdasarkan keseluruhan persepsi mengenai karakteristik Nokia Life Tools, responden tetap menilai baik meskipun masih dinilai cukup rumit. Hal ini dapat terjadi karena layanan ini merupakan inovasi pertama yang dikeluarkan produsen perangkat komunikasi (ponsel) yang dapat menyediakan informasi seputar pertanian dengan berbasis sistem SMS.

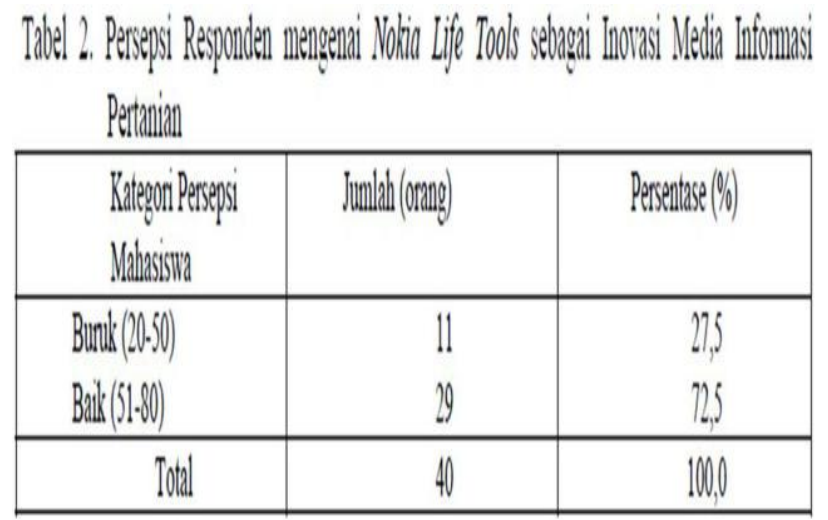

Nokia merupakan perangkat komunikasi pertama dan satu-satunya yang menawarkan layanan bagi masyarakat pedesaan terutama masyarakat petani. Berbagai jenis layanan yang disediakan, yaitu agrikultur, edukasi, dan hiburan merupakan hasil riset yang melibatkan masyarakat desa secara langsung. Oleh karena itu berbagai informasi yang ditawarkan dalam Nokia Life Tools sesuai dengan kebutuhan masyarakat desa akan informasi pertanian saat ini. Sebagai salah satu stakeholder pada bidang pertanian yang cukup memiliki pengetahuan dan pengalaman mengenai sektor pertanian, tentunya mahasiswa pertanian dapat mempersepsikan atau menilai apakah Nokia Life Tools baik atau tidak untuk digunakan sebagai inovasi yang menyediakan informasi seputar pertanian

\section{Hubungan Jenis Kelamin dengan Persepsi Responden mengenai Nokia Life Tools}

Hubungan karakteristik jenis kelamin responden diuji dengan menggunakan uji Crosstab Chi-Square. Data hubungan antara jenis kelamin dengan persepsi responden secara ringkas disajikan pada Tabel 3.

Berdasarkan data pada Tabel 3 didapatkan hasil bahwa dari 40 responden terdapat 45 persen laki-laki dan 55 persen perempuan. Dari 45 persen laki-laki, sebanyak 17,5 persen mempersepsikan Nokia Life Tools buruk dan 27,5 persen mempersepsikan baik. Dari 55 persen perempuan, 10 persen mempersepsikan Nokia Life Tools buruk dan 45 persen mempersepsikan baik. Nilai ChiSquare hitung lebih kecil dari pada Chi-Square tabel $(2,129<3,184)$ dengan nilai signifikansi lebih besar dari $0.05(0,145>0,05)$, artinya tidak ada hubungan nyata antara jenis kelamin dengan persepsi responden mengenai 
Nokia Life Tools. Tidak adanya hubungan juga dapat terlihat dari sebaran persepsi pada Tabel 3 dimana tidak ada perbedaan yang mencolok antara jumlah sebaran lakilaki dan perempuan dalam mempersepsikan Nokia Life Tools. Kedua jenis kelamin tersebut sebagian besar menilai Nokia Life Tools sebagai inovasi yang baik untuk pertanian.

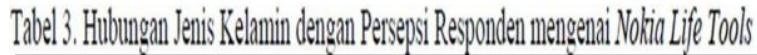

\begin{tabular}{|c|c|c|c|}
\hline \multirow[t]{2}{*}{ Jenis KRlaming } & \multicolumn{2}{|c|}{ Persensis (umandin) } & \multirow[t]{2}{*}{ Iotal } \\
\hline & Bund & Bailk & \\
\hline Laki-aldi & $7(17,5 \%)$ & $11(2,5 \%)$ & $18(45,0 \%)$ \\
\hline Peremoun & $4(10,0 \%)$ & $18(45,0 \%)$ & $22(55,0 \%)$ \\
\hline Iotal & $11(27,5 \%)$ & $29(72.5 \%)$ & $40(100,0 \%$ \\
\hline
\end{tabular}

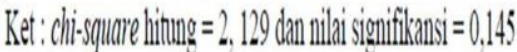

Tidak adanya perbedaan antara persepsi responden lakilaki dan perempuan dalam mempersepsikan Nokia Life Tools menunjukkan bahwa baik laki-laki maupun perempuan memiliki penilaian yang sama atas layanan Nokia Life Tools. Hal ini bisa terjadi karena tidak ada perbedaan atas layanan yang diberikan Nokia Life Tools baik untuk laki-laki maupun untuk perempuan.

\section{Hubungan Asal Daerah dengan Persepsi Responden mengenai Nokia Life Tools}

Hubungan antara asal daerah dengan persepsi responden mengenai Nokia Life Tools diuji dengan uji Crosstab ChiSquare. Uji ini dilakukan untuk menganalisis apakah asal daerah yang berbeda diikuti dengan persepsi yang berbeda juga. Data hubungan antara asal daerah dengan persepsi responden mengenai Nokia Life Tools disajikan pada Tabel 4.

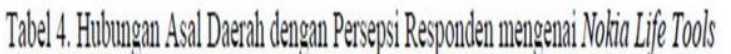

\begin{tabular}{|c|c|c|c|}
\hline \multirow[t]{2}{*}{ Asal Derenh } & \multicolumn{2}{|c|}{ 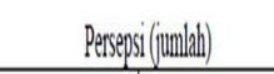 } & \multirow[t]{2}{*}{ Total } \\
\hline & Bundk & Ball & \\
\hline Desa & $7(17,5 \%$ & $7(1,7,5 \%)$ & $14(35,0 \%$ \\
\hline Kota & $4(10,0 \% \%)$ & $22(55,0,0)$ & $26(65,0 \%$ \\
\hline Iotal & $11(27,5 \%)$ & $29(725 \%)$ & $40(100 \%)$ \\
\hline
\end{tabular}

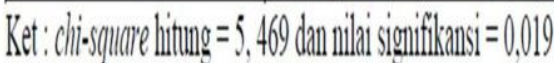

Tabel 4 menunjukkan hasil bahwa terdapat 35 persen responden Departemen Agronomi dan Hortikultura tahun masuk 2006 berasal dari desa dan 65 persen yang berasal dari kota. Dari 35 persen responden yang berasal dari desa, sebanyak 17,5 persen mempersepsikan Nokia Life Tools buruk dan 17,5 persen lainnya mempersepsikan Nokia Life Tools baik. Dari 65 persen responden yang berasal dari kota, sebanyak 10 persen mempersepsikan
Nokia Life Tools buruk dan 55 persen lainnya mempersepsikan Nokia Life Tools baik. Nilai Chi-Square hitung lebih besar dari nilai Chi-Square tabel $(5,469>$ 3,814 ) dengan nilai signifikansi lebih kecil dari 0,05 $(0,019<0,05)$, artinya terdapat hubungan nyata antara asal daerah dengan persepsi responden mengenai Nokia Life Tools. Hubungan tersebut juga dapat terlihat dari perbedaan persepsi antara responden yang berasal dari desa dengan yang berasal kota. Responden yang berasal dari kota lebih banyak yang mempersepsikan Nokia Life Tools baik. Sementara itu responden yang berasal dari desa sama jumlahnya antara yang mempersepsikan buruk dengan yang mempersepsikan baik.

\section{Hubungan Pekerjaan Orang Tua dengan Persepsi Responden mengenai Nokia Life Tools}

Pekerjaan orang tua merupakan pekerjaan pokok yang menjadi sumber pendapatan utama bagi orang tua responden pada penelitian ini. Berdasarkan kuesioner yang telah disebarkan kepada responden, pekerjaan orang tua pada penelitian ini dikategorikan menjadi Pegawai Negeri Sipil (PNS), karyawan swasta, wiraswasta, petani, dan lainnya. Dalam mempersepsikan Nokia Life Tools, diduga terdapat hubungan antara pekerjaan orang tua dengan persepsi mahasiswa mengenai Nokia Life Tools. Hubungan antara pekerjaan orang tua dengan persepsi responden mengenai Nokia Life Tools diuji dengan menggunakan uji Crosstab Chi-Square. Data hubungan antara pekerjaan orang tua dengan persepsi responden disajikan pada Tabel 5.

Penjabaran data pada Tabel 5 menunjukkan bahwa terdapat 45 persen orang tua mahasiswa bekerja sebagai PNS, 17 persen karyawan swasta, 20 persen wiraswasta, 12,5 persen petani, dan lima persen bekerja pada sektor lainnya. Dari 45 persen responden yang orang tuanya bekerja sebagai petani, sebanyak 15 persen mempersepsikan buruk Nokia Life Tools dan 30 persen mempersepsikan baik. Dari 17,5 persen responden yang orang tuanya bekerja sebagai karyawan swasta, sebanyak lima persen mempersepsikan buruk dan 12,5 persen mempersepsikan baik. Dari 20 persen yang orang tuanya bekerja sebagai wiraswasta, semuanya mempersepsikan baik dan tidak ada yang mempersepsikan buruk. Dari 12,5 persen responden yang orang tuanya bekerja sebagai petani, sebanyak lima persen mempersepsikan buruk dan 10 persen lainnya mempersepsikan baik. Dari lima persen responden yang orang tuanya bekerja di sektor lainnya, seluruhnya mempersepsikan buruk. Nilai Chi-Square hitung lebih kecil dari nilai Chi-Square tabel $(8,760<$ $9,488)$ dengan nilai signifikansi lebih besar dari 0,05 $(0,067>0,05)$, artinya tidak ada hubungan nyata antara pekerjaan orang tua dengan persepsi responden mengenai Nokia Life Tools. Tidak adanya perbedaan persepsi berdasarkan jenis pekerjaan orang tua mahasiswa menunjukkan bahwa Nokia Life Tools dapat diterima oleh mahasiswa sebagai suatu inovasi apapun latar belakang keluarganya. 


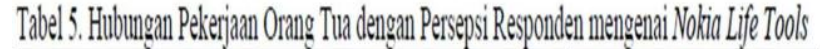

\begin{tabular}{|c|c|c|c|}
\hline \multirow[t]{2}{*}{ Pekerianan Orang Tha } & \multicolumn{2}{|c|}{ Persepsi (umaland) } & \multirow[t]{2}{*}{ Iotal } \\
\hline & Bundk & Baik & \\
\hline PNS & $6(15,0 \%)$ & $12(30,0 \%)$ & $18(5,0 \%)$ \\
\hline Karajaran Strasta & $2(5,0 \%)$ & $5(12,5 \%)$ & $7(17,5 \%)$ \\
\hline Wirsarsatata & $0(0,0 \%)$ & $8(20,0 \%)$ & $8(20,0 \%)$ \\
\hline Petani & $1(2,5 \%)$ & $4(10,0 \%)$ & $5(12,5 \%)$ \\
\hline Lamya & $2(5,0 \%)$ & $0(0,0 \%)$ & $2(5,0 \%)$ \\
\hline Total & $11(27,5 \%)$ & $29(225 \%)$ & $40(100 \%)$ \\
\hline
\end{tabular}

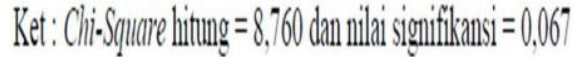

\section{Hubungan Uang Bulanan dengan Persepsi Responden mengenai Nokia Life Tools}

Diduga terdapat hubungan antara uang bulanan yang diterima responden dengan persepsi responden mengenai Nokia Life Tools. Hubungan antara uang bulanan dengan persepsi responden mengenai Nokia Life Tools diuji dengan uji korelasi Rank Spearman. Data hubungan antara uang bulanan dengan persepsi responden mengenai Nokia Life Tools disajikan pada Tabel 6.

Tabel 6 menunjukkan terdapat 20 persen responden memiliki besarnya uang bulanan termasuk dalam kategori rendah, 67,5 persen memiliki besarnya uang bulanan kategori sedang, dan 12,5 persen lainnya memiliki besarnya uang bulanan kategori tinggi. Dari 20 persen responden yang memiliki besarnya uang bulanan rendah, sebanyak lima persen mempersepsikan buruk Nokia Life Tools dan 15 persen lainnya mempersepsikan baik.

Dari 67,5 persen responden yang besar uang bulananannya sedang, sebanyak 17,5 persen mempersepsikan buruk dan 50 persen mempersepsikan baik. Dari 12,5 persen responden yang besar uang bulanannya tinggi, sebanyak lima persen mempersepsikan baik dan 7,5 persen mempersepsikan buruk. Nilai signifikansi lebih besar dari 0,05 $(0,471>0,05)$, artinya tidak ada hubungan signifikan antara besarnya uang bulanan dengan persepsi responden mengenai Nokia Life Tools. Tidak adanya hubungan antara besarnya uang bulanan responden dengan persepsinya mengenai Nokia Life Tools menunjukkan bahwa Nokia Life Tools sebagai suatu inovasi dapat diterima oleh semua kalangan.

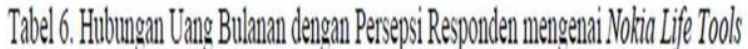

\begin{tabular}{|c|c|c|c|}
\hline \multirow[t]{2}{*}{ Bexamya Vang Bulanan } & \multicolumn{2}{|c|}{ 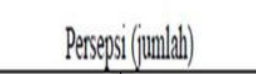 } & \multirow[t]{2}{*}{ Iotal } \\
\hline & Bundu & Balk & \\
\hline Rendal & $2(5,0 \%)$ & $6(15,0 \%)$ & $8(20,0 \%)$ \\
\hline Selengy & $7(1,7,5 \%)$ & $20(50,0 \%)$ & $27(6,5 \%)$ \\
\hline Timgog & $2(5,0 \%)$ & $3(7,5 \%)$ & $5(12,5 \%)$ \\
\hline Iotal & $11(20,5 \%)$ & $29(2,5 \%)$ & $40(100,0 \%)$ \\
\hline
\end{tabular}

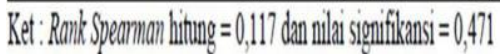

Hubungan Kepemilikan Ponsel dengan Persepsi Responden mengenai Nokia Life Tools

Hubungan antara kepemilikan ponsel dengan persepsi responden mengenai Nokia Life Tools diuji dengan uji Crosstab Chi-Square. Data hubungan kepemilikan ponsel dengan persepsi responden mengenai Nokia Life Tools disajikan pada Tabel 7 .

Merujuk data pada Tabel 7 dapat diketahui sebaran persepsi responden pada penelitian ini mengenai Nokia Life Tools berdasarkan kepemilikan ponsel. Berdasarkan Tabel dapat diketahui bahwa terdapat 20 persen responden yang menggunakan ponsel non-nokia dan 80 persen lainnya menggunakan ponsel Nokia.

Dari 20 persen responden yang menggunakan ponsel nonnokia terdapat 10 persen responden mempersepsikan Nokia Life Tools buruk dan 10 persen lainnya mempersepsikan baik. Dari 80 persen responden yang menggunakan ponsel Nokia, 12,5 persen mempersepsikan Nokia Life Tools buruk dan 62,5 persen mempersepsikan baik. Nilai Chi-Square hitung lebih kecil daripada nilai Chi-Square tabel $(2,539<3,841)$ dengan nilai signifikansi lebih besar dari $0,05(0,111>0,05)$, artinya tidak ada hubungan nyata antara kepemilikan ponsel dengan persepsi responden mengenai Nokia Life Tools.

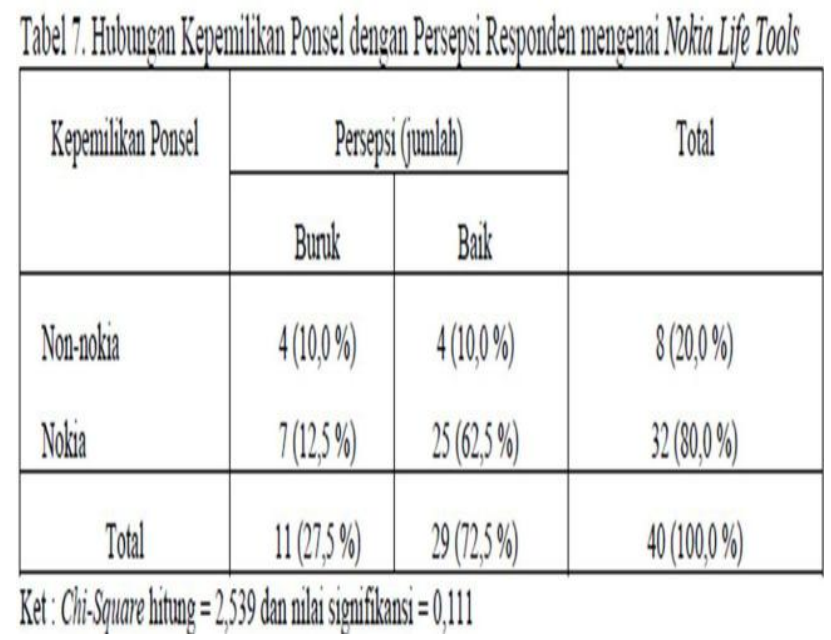

Hubungan Tingkat Penggunaan Ponsel dengan Persepsi Responden mengenai Nokia Life Tools 
Hubungan antara tingkat penggunaan ponsel dengan persepsi responden mengenai Nokia Life Tools duji dengan uji korelasi Rank Spearman. Data hubungan antara tingkat penggunaan ponsel masing-masing dibedakan atas fitur yang digunakan, yaitu fitur telepon, SMS, dan internet.

Salah satu fitur ponsel yang banyak digunakan oleh para pengguna ponsel adalah telepon. Data hubungan tingkat penggunaan ponsel untuk telepon dengan persepsi mahasiswa yang menjadi responden mengenai Nokia Life Tools disajikan pada Tabel 8 seperti berikut.

\begin{tabular}{|c|c|c|c|}
\hline \multirow[t]{2}{*}{ Iinglat Pengenumanan Telepon } & \multicolumn{2}{|c|}{ 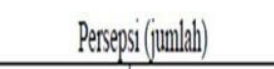 } & \multirow[t]{2}{*}{ Iotal } \\
\hline & Bunls & Badk & \\
\hline 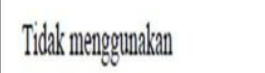 & $1(2,5 \%)$ & $8(20,0 \%)$ & $9(2,5,5 \%)$ \\
\hline Jarang & $9(22,5 \%)$ & $15(37,5 \%)$ & $24(0,0,0 \%)$ \\
\hline Sering & $1(2,5 \%)$ & $6(15,0 \%)$ & $7(17,5 \%)$ \\
\hline Total & $11(27,5 \%)$ & $29(72,5 \%)$ & $40(100,0 \%)$ \\
\hline
\end{tabular}

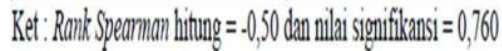

Sebaran persepsi pada Tabel 8 menunjukkan bahwa sebanyak 22,5 persen responden tidak menggunakan fitur ponsel untuk telepon, 60 persen jarang menggunakan ponsel untuk telepon, dan 17,5 persen sisanya sering menggunakan ponsel untuk telepon. Dari 22,5 persen responden yang tidak menggunakan ponsel untuk telepon, sebanyak 2,5 persen yang mempersepsikan Nokia Life Tools buruk dan 20 persen yang mempersepsikan Nokia Life Tools baik. Dari 60 persen yang jarang menggunakan fitur ponsel untuk telepon, sebanyak 22,5 persen mempersepsikan Nokia Life Tools buruk dan 37,5 persen mempersepsikan Nokia Life Tools baik. Dari 17,5 persen responden yang sering menggunakan ponsel untuk telepon, sebanyak 2,5 persen mempersepsikan Nokia Life Tools buruk dan 15 persen mempersepsikan Nokia Life Tools baik. Nilai signifikansi lebih besar dari 0,05 (0,760 $>0,05)$, artinya tidak ada hubungan signifikan antara tingkat penggunaan ponsel untuk telepon dengan persepsi responden terhadap Nokia Life Tools. Fitur SMS pada ponsel juga merupakan salah satu fitur ponsel yang banyak digunakan oleh para pengguna ponsel. Data hubungan tingkat penggunaan ponsel untuk SMS dengan persepsi responden mengenai Nokia Life Tools disajikan pada Tabel 9.

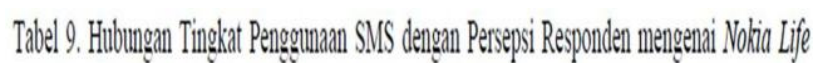
Tools

\begin{tabular}{|c|c|c|c|}
\hline \multirow[t]{2}{*}{ Tinglat Pengyumanan SUS } & \multicolumn{2}{|c|}{ Persesisi (umlanda) } & \multirow[t]{2}{*}{ Total } \\
\hline & Bundk & Bailk & \\
\hline 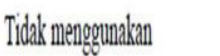 & $0(0,0 \%)$ & $1(2,5 \%)$ & $1(2,5 \%)$ \\
\hline Jarang & $10(25,5 \%)$ & $25(0.25 \%)$ & $35(87,5 \%)$ \\
\hline Sering & $1(2,5 \%)$ & $3(1,5 \%)$ & $4(10,0 \%)$ \\
\hline Iotal & $11(27,5 \%)$ & $29(2,5 \%)$ & $40(100, \% \%)$ \\
\hline
\end{tabular}

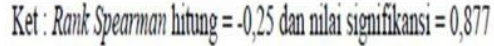

Berdasarkan hasil pada Tabel 9 dapat diketahui bahwa sebanyak 2,5 persen tidak menggunakan ponsel untuk SMS, 87,5 persen jarang menggunakan ponsel untuk SMS, dan 10 persen sering menggunakan ponsel untuk SMS. Responden yang tidak menggunakan ponsel untuk SMS mempersepsikan Nokia Life Tools baik. Dari 87,5 persen responden yang jarang menggunakan ponsel untuk SMS, sebanyak 25 persen mempersepsikan Nokia Life Tools buruk dan 62,5 persen mempersepsikan Nokia Life Tools baik. Dari 10 persen responden yang sering menggunakan ponsel untuk SMS, sebanyak 2,5 persen mempersepsikan Nokia Life Tools buruk dan 7,5 persen mempersepsikan baik. Nilai signifikansi lebih besar dari $0,05(0,877>0,05)$, artinya tidak ada hubungan signifikan antara tingkat penggunaan ponsel untuk SMS dengan persepsi responden mengenai Nokia Life Tools.

Fitur ponsel lainnya yang sering digunakan oleh penggunanya selain fitur telepon dan SMS adalah layanan internet pada ponsel. Data hubungan antara tingkat penggunaan ponsel untuk internet dengan persepsi responden mengenai Nokia Life Tools disajikan pada Tabel 10.

Tabel 10 menunjukkan sebaran persepsi mahasiswa, dimana sebanyak 32,5 persen responden tidak menggunakan ponsel untuk internet, 55 persen jarang menggunakan ponsel untuk internet, dan 12,5 persen sering menggunakan ponsel untuk internet. Dari 32,5 persen responden yang tidak menggunakan fitur ponsel untuk internet, sebanyak 7,5 persen mempersepsikan Nokia Life Tools buruk dan 25 persen mempersepsikan Nokia Life Tools baik. Dari 55 persen responden yang jarang menggunakan fitur ponsel untuk internet, sebanyak 17,5 persen mempersepsikan Nokia Life Tools buruk dan 25 persen mempersepsikan Nokia Life Tools baik. Dari 12,5 persen responden yang sering menggunakan fitur ponsel untuk internet, sebanyak 2,5 persen mempersepsikan Nokia Life Tools buruk dan 10 persen lainnya mempersepsikan Nokia Life Tools baik. Nilai signifikansi lebih besar dari 0,05 $(0,453>0,05)$, artinya tidak ada hubungan signifikan antara tingkat penggunaan ponsel untuk internet dengan persepsi responden mengenai Nokia Life Tools.

Dari penjabaran tingkat penggunaan ketiga fitur ponsel tersebut, tidak terlihat adanya hubungan signifikan antara 
tingkat penggunaan ponsel dengan persepsi responden mengenai Nokia Life Tools. Tidak adanya hubungan juga terlihat dari sebaran persepsi responden berdasarkan tingkat penggunaan fitur-fitur ponsel tersebut. Tidak terlihat adanya perbedaan persepsi yang menonjol pada masing-masing kategori untuk tingkat penggunaan fitur ponsel. Sebagian besar responden pada masing-masing kategori tingkat penggunaan ponsel mempersepsikan Nokia Life Tools sebagai suatu inovasi yang baik.

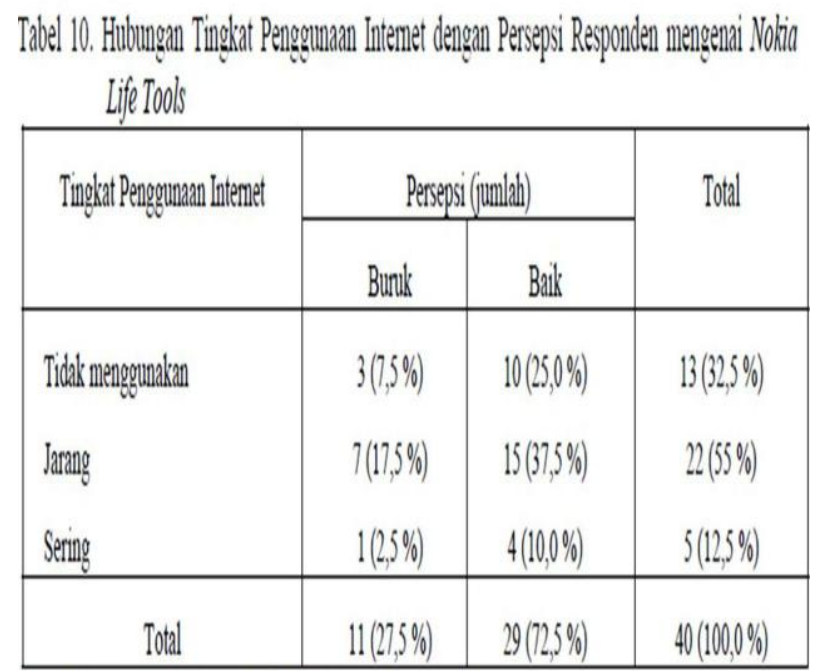

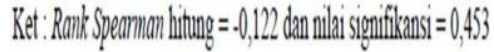

\section{Hubungan Tingkat Pengetahuan dengan Persepsi Responden mengenai Nokia Life Tools}

Hubungan antara tingkat pengetahuan dengan persepsi responden diuji dengan uji korelasi Rank Spearman. Data hubungan tingkat keterdedahan iklan layanan Nokia Life Tools disajikan pada Tabel 11.

Tabel 11 menunjukkan hasil bahwa terdapat 22,5 persen responden yang memiliki tingkat pengetahuan rendah, 50 persen memiliki tingkat pengetahuan sedang, dan 27,5 persen yang memiliki tingkat pengetahuan tinggi. Dari 22,5 persen responden yang tingkat pengetahuannya rendah seluruhnya mempersepsikan Nokia Life Tools buruk. Dari 50 persen responden yang tingkat pengetahuannya sedang sebanyak lima persen yang mempersepsikan Nokia Life Tools buruk dan 45 persen lainnya mempersepsikan baik. Dari 27,5 persen responden yang memiliki tingkat pengetahuan tinggi seluruhnya mempersepsikan Nokia Life Tools baik. Nilai signifikansi lebih kecil dari $0,05(0,000<0,005)$, artinya terdapat hubungan yang sangat signifikan antara tingkat pengetahuan dengan persepsi responden mengenai Nokia Life Tools.

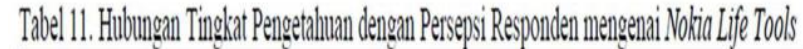

\begin{tabular}{|c|c|c|c|}
\hline \multirow[t]{2}{*}{ Tinglat Pengetahuan } & \multicolumn{2}{|c|}{ Persepsi(jumlan) } & \multirow[t]{2}{*}{ Total } \\
\hline & Bunds & Baik & \\
\hline $\operatorname{Rendan}(0-3)$ & $9(22,5 \%)$ & $0(0,0 \%)$ & $9(2,5 \%)$ \\
\hline Seddang (4.0) & $2(5,0 \%)$ & $18(45,0 \%)$ & $20(50,0 \%)$ \\
\hline $\operatorname{Iingg}(7 \cdot 10)$ & $0(0,0 \%)$ & $11(2,7,5 \%)$ & $11(2,7 \%)$ \\
\hline Total & $11(27,5 \%)$ & $29(72,5 \%)$ & $40(100,0 \%)$ \\
\hline
\end{tabular}

Ket: Rank Speannan uitung $=0,77$ dan nilai signififikansi $=0,000$

Hubungan Keterdedahan Media Massa dengan
Persepsi Responden mengenai Nokia Life Tools

Hubungan antara keterdedahan mahasiswa atas media massa dengan persepsi mahasiswa mengenai Nokia Life Tools diuji dengan uji Crosstab Chi-Square. Pada Tabel 12 disajikan hubungan keterdedahan mahasiswa terhadap televisi sebagai media massa dengan persepsi mahasiswa Departemen Agronomi dan Hortikultura tahun masuk 2006 mengenai Nokia Life Tools.

Hasil pada Tabel 12 menunjukkan bahwa sebanyak lima persen responden tidak terdedah dengan televisi setiap harinya dan 95 persen lainnya terdedah dengan media televisi setiap hari. Responden yang tidak terdedah dengan televisi setiap hari mempersepsikan baik Nokia Life Tools. Dari 95 persen responden yang terdedah televisi setiap hari, sebanyak 27,5 persen yang mempersepsikan Nokia Life Tools buruk dan 67,5 persen lainnya mempersepsikan baik. Nilai Chi-Square hitung lebih kecil dari dari nilai Chi-Square tabel $(0,799<3,841)$ dengan nilai signifikansi lebih besar dari $0,05(0,372>$ $0,05)$, artinya tidak ada hubungan nyata antara keterdedahan responden atas media televisi dengan persepsi responden mengenai Nokia Life Tools.

Merujuk Tabel 13 didapatkan hasil bahwa dari 40 responden, yang terdedah dengan radio setiap hari sebanyak 25 persen dan 75 persen lainnya tidak terdedah dengan radio setiap hari. Dari 25 persen responden yang terdedah dengan radio setiap hari, sebanyak 10 persen mempersepsikan buruk Nokia Life Tools dan 15 persen mempersepsikan baik.

Dari 75 persen responden yang tidak terdedah dengan radio setiap hari, sebanyak 17,5 persen mempersepsikan buruk Nokia Life Tools dan 57,5 persen lainnya mempersepsikan baik. Nilai Chi-Square hitung lebih kecil dari nilai Chi-Square tabel $(1,045<3,841)$ dengan nilai signifikansi lebih besar dari $0,05(0,307>0,05)$, artinya tidak ada hubungan nyata antara keterdedahan responden terhadap radio dengan persepsi responden mengenai Nokia Life Tools. 
Tabel 12. Hibungan Keterdedathan Responden techadap teleris dengan Pessepsi Responden mengenai Nohia Life Tools

\begin{tabular}{|c|c|c|c|}
\hline \multirow[t]{2}{*}{ Reterdededhan terinatop Telerisi } & \multicolumn{2}{|c|}{ Persepsis (umalata) } & \multirow[t]{2}{*}{ Total } \\
\hline & Bund & Bailik & \\
\hline Tidak & $0(0,0 \%)$ & $2(5,0 \%)$ & $2(5,0 \%)$ \\
\hline$Y_{a}$ & $11(20,5 \%$ & $27(0,5 \%)$ & $38(5,0,0 \%)$ \\
\hline Total & $11(02,5 \%$ & $20(2,5 \%)$ & $40(100,0 \%)$ \\
\hline
\end{tabular}

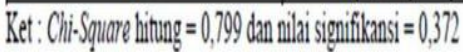

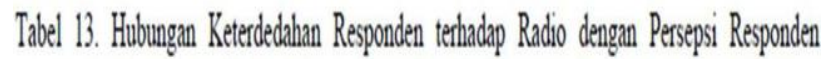
menerenai Nohia Life Tools

\begin{tabular}{|c|c|c|c|}
\hline \multirow[t]{2}{*}{ Reterdedanan termadep Radio } & \multicolumn{2}{|c|}{ Persensi (umandar) } & \multirow[t]{2}{*}{ Total } \\
\hline & Bunds & Baik & \\
\hline Tidak & $7(17,5 \%)$ & $3(77,5 \%)$ & $30(33,0 \%)$ \\
\hline$Y_{a}$ & $4(10,0 \%)$ & $6(15,0 \%)$ & $10(25,0 \%)$ \\
\hline Total & $11027,5 \%$ & $20(725 \%)$ & $40(100,0 \%)$ \\
\hline
\end{tabular}

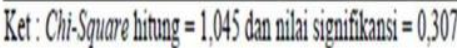

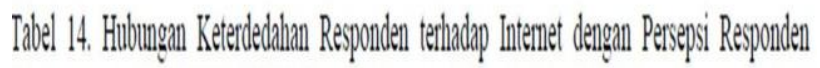
menemenai Yoka Life Tools

\begin{tabular}{|c|c|c|c|}
\hline \multirow[t]{2}{*}{ 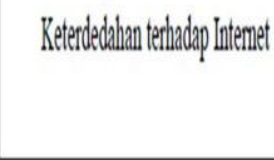 } & \multicolumn{2}{|c|}{ Pespessif(umandin) } & \multirow[t]{2}{*}{ Iotal } \\
\hline & Bund & Badk & \\
\hline Tidals & $0(0,0 \%)$ & $1(2,5 \%)$ & $1(2.5 \%)$ \\
\hline$Y_{a}$ & $11(20,5 \%)$ & $28(0,0,0 \%)$ & $39(9,5 \%)$ \\
\hline Total & $11(20,5 \%)$ & $29(225 \%)$ & 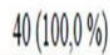 \\
\hline
\end{tabular}

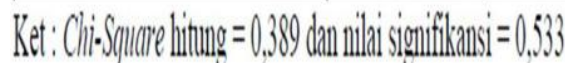

Sebaran persepsi responden pada Tabel 14 menunjukkan bahwa sebanyak 2,5 persen responden tidak terdedah terhadap internet setiap hari dan 97,5 persen lainnya terdedah terhadap internet setiap hari. Dari 97,5 persen responden yang terdedah terhadap internet setiap hari, sebanyak 27,5 persen yang mempersepsikan buruk Nokia Life Tools dan 70 persen lainnya mempersepsikan baik. Responden yang tidak terdedah dengan internet setiap hari mempersepsikan Nokia Life Tools sebagai suatu inovasi yang baik. Nilai Chi-Square hitung lebih kecil daripada nilai Chi-Square tabel $(0,389<3,841)$ dan nilai signifikansi lebih besar dari $0,05(0,533>0,05)$, artinya tidak ada hubungan nyata antara keterdedahan responden terhadap internet dengan persepsi responden mengenai Nokia Life Tools.
Tabel 15 menunjukkan bahwa mahasiswa Departemen Agronomi dan Hortikultura tahun masuk 2006 yang menjadi responden berdasarkan keterdedahannya pada koran/majalah, yang terdedah dengan koran/majalah setiap hari, yaitu sebanyak 55 persen dan 45 persen lainnya lainnya tidak terdedah dengan koran/majalah setiap hari. Dari 45 persen responden yang tidak terdedah dengan koran/majalah setiap hari, sebanyak 7,5 persen mempersepsikan buruk Nokia Life Tools dan 37,5 persen mempersepsikan baik. Dari 55 persen responden yang terdedah dengan koran/majalah setiap hari, sebanyak 20 persen mempersepsikan buruk Nokia Life Tools dan 35 persen mempersepsikan baik.

Nilai Chi-Square hitung lebih kecil daripada nilai ChiSquare tabel $(1,926<3,841)$ dengan nilai signifikansi lebih besar dari $0,05(0,165>0,05)$, artinya tidak ada hubungan nyata antara keterdedahan terhadap koran/majalah dengan persepsi responden mengenai Nokia Life Tools.

Tidak adanya hubungan antara keterdedahan responden terhadap koran/majalah dengan persepsinya mengenai Nokia Life Tools juga dapat dilihat dari sebaran persepsi masing-masing kategori pada Tabel 15, dimana tidak terdapat perbedaan yang cukup berarti antara persepsi responden yang terdedah dengan koran/majalah setiap harinya dengan yang tidak. Sebagian besar mahasiswa yang menjadi responden, baik yang terdedah dengan koran/majalah setiap maupun yang tidak, mempersepsikan Nokia Life Tools sebagai suatu inovasi yang baik sebagai media informasi pertanian.

Dari penjabaran hubungan keterdedahan responden terhadap masing-masing media massa (televisi, radio, internet, koran/majalah) dengan persepsinya mengenai Nokia Life Tools tidak terlihat adanya hubungan nyata antara keterdedahan media massa dengan persepsi mahasiswa Departemen Agronomi dan Hortikultura tahun masuk 2006 yang menjadi responden pada penelitian ini mengenai Nokia Life Tools. Apapun jenis media massa yang digunakan oleh mahasiswa dalam mendapatkan informasi setiap harinya, sebagian besar dari mereka dapat menerima Nokia Life Tools sebagai suatu inovasi yang baik.

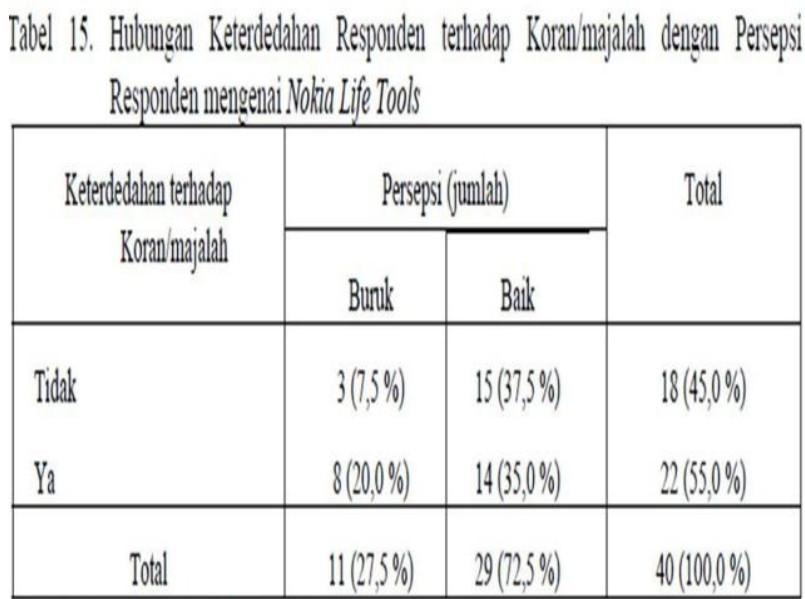

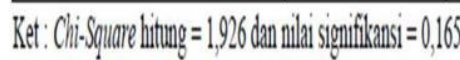




\section{Hubungan Tingkat Keterdedahan Iklan Layanan dengan Persepsi Responden Mengenai Nokia Life Tools}

Hubungan antara tingkat keterdedahan iklan layanan dengan persepsi responden mengenai Nokia Life Tools diuji dengan uji korelasi Rank Spearman. Uji ini dilakukan untuk menganalisis apakah perbedaan tingkat keterdedahan iklan layanan diikuti dengan perbedaan persepsi responden mengenai Nokia Life Tools. Data hubungan tingkat keterdedahan iklan dengan persepsi responden mengenai Nokia Life Tools disajikan pada Tabel 16.

Data pada Tabel 16 menunjukkan bahwa sebanyak 70 persen responden memiliki tingkat keterdedahan terhadap iklan layanan tergolong kategori sedang dan 30 persen memiliki tingkat keterdedahan terhadap iklan layanan tergolong kategori tinggi.

Tabel 16. Hubungan Tingkat Keterdedahan Iklan Layanan dengan Persepsi Responden mengenai
Nokia Life Tools
\begin{tabular}{|l|l|l|l|}
\hline \multicolumn{2}{|l|}{ Kategori Tingkat Keterdedahan } & Persepsi (jumlah) & \multicolumn{1}{|l|}{ Total } \\
\hline Iklan (skor) & Bunuk & Baik & \\
\hline$(3-4)$ Sedang & $11(27,5 \%)$ & $17(42,5 \%)$ & $28(70,0 \%)$ \\
$(5-6)$ Tinggi & $0(0,0 \%)$ & $12(30,0 \%)$ & $12(30,0 \%)$ \\
\hline Total & $11(27,5 \%)$ & $29(72,5 \%)$ & $40(100,0 \%)$ \\
\hline
\end{tabular}

\section{Ket: Rank Spearman hitung $=0,403$ dan nulai signifikansi $=0,010$}

Dari 70 persen responden yang memiliki tingkat keterdedahan sedang terhadap iklan layanan, sebanyak 27,5 persen mempersepsikan Nokia Life Tools buruk dan 42,5 persen lainnya mempersepsikan baik. Dari 30 persen responden yang memiliki tingkat keterdedahan tinggi terhadap iklan layanan seluruhnya mempersepsikan Nokia Life Tools baik. Nilai signifikansi lebih kecil dari 0,05 $(0,010<0,05)$, artinya terdapat hubungan signifikan antara tingkat keterdedahan iklan layanan dengan persepsi responden mengenai Nokia Life Tools.

\section{PENUTUP}

\section{Kesimpulan}

1. Responden pada penelitian ini mempersepsikan Nokia Life Tools berdasarkan karakteristiknya sebagai inovasi, yaitu keuntungan relatif yang sedang, cukup sesuai, cukup rumit, cukup mudah untuk dicoba, dan cukup mudah untuk dilihat hasilnya. Secara umum mahasiswa Departemen Agronomi dan Hortikultura tahun masuk 2006 yang menjadi responden mempersepsikan Nokia Life Tools sebagai inovasi yang baik dalam menyediakan informasi pertanian.

2. Karakteristik personal yang berhubungan nyata dengan persepsi responden mengenai Nokia Life Tools adalah asal daerah responden dan tingkat pengetahuan responden mengenai Nokia Life Tools. Sedangkan jenis kelamin, besarnya uangbulanan, pekerjaan orang tua, kepemilikan ponsel, dan tingkat penggunaan ponsel tidak berhubungan nyata dengan persepsi mahasiswa mengenai Nokia Life Tools.
3. Tingkat keterdedahan responden terhadap informasi ditinjau dari keterdedahannya terhadap media massa dan tingkat keterdedahan terhadap iklan layanan Nokia Life Tools. Tingkat keterdedahan responden terhadap iklan layanan Nokia Life Tools memiliki hubungan signifikan dengan persepsi respponden mengenai layanan tersebut, sedangkan keterdedahan responden terhadap media massa tidak berhubungan dengan persepsi responden mengenai Nokia Life Tools.

\section{Saran}

1. Bagi penyedia layanan, pihak Nokia sebaiknya menambah promosinya untuk Nokia Life Tools terutama dalam hal manfaat dan cara menggunakannya melalui berbagai media informasi, sehingga dapat diterima masyarakat dengan baik.

2. Bagi masyarakat, sebaiknya mencoba layanan Nokia Life Tools sesuai dengan kebutuhannya. Terutama bagi masyarakat petani sebagai sasaran utama agar dapat merasakan manfaat informasi yang ditawarkan pada layanan tersebut dan dapat mengembangkan usaha pertaniannya.

3. Bagi sivitas akademika, sebaiknya dilakukan penelitian lebih lanjut mengenai layanan Nokia Life Tools, terutama dalam hal persepsi masyarakat petani mengenai kesesuaian informasi pada layanan dengan kebutuhan masyarakat petani.

\section{DAFTAR PUSTAKA}

Anonim. 2009. www.nokia.co.id/tentangnokia/perusahaan diakses tanggal 7 April 2010.

Cangara, H. Hafied. 2006. Pengantar Ilmu Komunikasi. PT Raja Grafindo Persada. Jakarta

Dimas. 2009. Nokia Life Tools Resmi diluncurkan di Indonesia.

www.tempointeraktif.com/.../brk,20091104206360,id.html diakses tanggal 7 April 2010.

Ibrahim, Jabal Tarik. 2003. Komunikasi dan Penyuluhan Pertanian. Bayu-Media Publishing \& UMM Press. Malang.

Kristian. 2009. Apa sih Nokia Life Tools?. nokiaweblog.com/2009/11/04/apa-sih-nokialifetools/ diakses tanggal 7 April 2010.

Mardalis. 2004. Metode Penelitian (Suatu Pendekatan Proposal) Edisi 1, Cetakan 7. Bumi Aksara. Jakarta.

Mardikanto, Totok. 1998. Komunikasi Pembangunan. Sebelas Maret University Press. Surakarta.

Mugniesyah. 2010. Media Komunikasi dan Komunikasi Massa dalam Aida Vitayala ed.

Dasar-dasar Komunikasi. Departemen Komunikasi dan Pengembangan Masyarakat. IPB.

Mulyana, Deddy. 2001. Ilmu Komunikasi Suatu Pengantar. PT Rosdakarya. Bandung. 
Mulyandari, Retno Sri Hartati, dan E. Eko Ananto. 2005. Teknik Implementasi Pengembangan Sumber Informasi Pertanian Nasional dan P4MI. Informatika Pertanian vol. 14.

Mulyanta, Edi S. 2003. Kupas Tuntas Telepon Seluler Anda. ANDI. Yogyakarta.

Rahardjo, Budi. 2002. Memahami Teknologi Informasi. Menyikapi dan Membekali Diri terhadap Peluang dan Tantangan Teknologi Informasi. PT. Elex Media. Jakarta.

Rakhmat, Jalaluddin. 2001. Psikologi Komunikasi. PT Remaja Rosdakarya. Bandung.

Rogers, Everett M. 2003. Diffusion of Innovation: fifth edition. The Free Press. New York.

Sarwono, Sarlito Wirawan. 2002. Psikologi Sosial: Individu dan Teori-Teori Psikologi Sosial. Balai Pustaka. Jakarta.

Setiadi, N.J. 2003. Perilaku Konsumen: Konsep dan Perilaku Untuk Strategi dan Penelitian Pemasaran. Prenada Media. Jakarta.

Singarimbun, Masri dan Sofian Effendi. 1989. Metode Penelitian Survai. LP3ES. Jakarta. Jakarta.

Suhendar, A. 2003. Teknologi Pemrograman Mobile Commerce. Informatika Bandung. Bandung.

Sunomo. 2003. Pengantar Sistem Komunikasi Nirkabel. Direktorat Jenderal Pendidikan Tinggi. Jakarta.

Umar, Husein. 2003. Riset Sumber Daya Manusia. PT Gramedia Pustaka Utama. Jakarta.

Widiantoro, Fajar. 2009. Sekilas tentang Nokia Life Tools. www.detikinet.com diakses tanggal 7 April 2010 . 